\title{
10. Doing Business in Latin America the Australian Way: Debunking myths about cross-cultural sensitivities
}

\author{
Bob Hodge
}

\section{Introduction}

Australians wanting to do business in the countries of Latin America need to understand the people they are doing business with. That means knowing more about these countries, past and present. The present book aims to provide some of that necessary knowledge. It also means as Australians we take a good hard look at ourselves: how we present ourselves and how we are likely to be interpreted by people from these countries, for both good and ill. These are considerations that the business community needs to take on board. This chapter will argue the necessity for greater cultural sensitivity, not less. Cultural sensitivity along these lines is good business and good policy.

Yet to foster more of the right kind of cultural sensitivity, we need to clear away some potent myths about cultural sensitivity that hinder better practices in understanding and relating to Latin American people as partners, competitors, customers, workmates and friends. This chapter takes on this complex double challenge: to debunk some of the myths but to do so constructively, with positive advice so that Australians will feel more confident to manage a wide range of relationships.

The chapter is written for three kinds of stakeholder. The government is already involved in promoting links with Latin America, especially through Austrade and through its support for the Council on Australia Latin America Relations (COALAR). Governments are naturally most interested in the macro-level: in relations between nations. This chapter will argue that important as they are, governmental relations are not the only drivers of the complex and growing network of relations between Australia and Latin America: social, cultural and business relations constitute the indispensable basis. The real drivers of change are individuals, engaged in business or wanting to extend their understanding of the world as Australians or Latin Americans. 


\section{On not being ashamed of being Australian}

The Australian Government sees a need to be involved in the task of creating better strategies and more favourable attitudes on the part of Australians towards the outside world, including Latin America. This is one of its functions in the new global environment in which businesses operate. Austrade has taken on board a special responsibility to promote this line of activities through its publications, in print and online. There is a wealth of documents now available online that offers crash courses in the new knowledge and approaches that are needed. ${ }^{1}$ Business people can and should use these as the first point of contact.

However, there is a common strand in these documents that may be counter-productive. I illustrate with a document first released in 2006, entitled Doing business in the United States. ${ }^{2}$ This text was criticised immediately on its release by popular journalist Frank Walker:

Don't make a joke if you want to sell anything to the Septics. Drop the Aussie self-deprecating humour and slip immediately into the 30-second hard fast sales pitch. Whoop and holler a lot. Give high fives just for pressing the lift-sorry, elevator-button.

If you want to do business with the Americans don't be a laconic, likeable and languid larrikin such as the archetypal Aussie Paul Hogan.

That's the message from Austrade, the government agency helping Australian companies flog goods overseas... ${ }^{3}$

Walker is not trying to be fair to Austrade, but this is a useful way into many key issues around the image of Australia, at home and abroad. His reaction is not what the Australian government wanted, but it is what many ordinary Australians actually think. When government and people diverge, it is unwise for business to trust only government.

The first point to focus on is what is summarised as the Austrade message: do not be a larrikin. Walker quotes David Howe, then senior trade commissioner in New York, in observing that Australian business employees should 'check their (Aussie) sense of humour at the door'. ${ }^{4}$ Austrade here is talking about how to succeed in the United States, not in Latin America, but the text is nonetheless equally relevant to the Latin American context. Austrade transmits a general

1 Austrade (Australian Trade Commission), http://www.austrade.gov.org.au.

2 Austrade (Australian Trade Commission) United States of America: Doing business, 2013: http:// www.austrade.gov.au/Export/Export-Markets/Countries/United-States-of-America/Doing-business\#. UlohDBCBHIE.

3 Frank Walker, 'Septics Are No Can Of Laughs', Sun Herald, 8 October 2006, p. 31.

4 Ibid. 
message that to be a 'typical Aussie' is a disadvantage. If it is a disadvantage in the United States, an Anglo-speaking culture like Australia, will it not be even more of a disadvantage in Latin America, with its Spanish or Portuguesespeaking cultures? Is being visibly Australian our source of shame, something to conceal at all costs? And if being Australian is such a mark of shame, how then do we market ourselves?

Walker offers this caricature of US business styles as our new model. Austrade's advice was not as simplistic as Walker implies. Yet on this occasion it does over-value the US style of doing business. Is this the best style even for Aussies in the USA? Walker doubts it. Might it be even less appropriate in Latin America?

The US style is a potent global brand: even in the wake of the global financial crisis the United States is the dominant economic force in all the Latin American nations with which Australia currently conducts most business: Brazil, Mexico, Chile, Argentina, Peru. However, paradoxically this dominance is a good reason for us not to check our Australianness at the door and disguise ourselves as wannabe Yanks. Latin American nations have a long tradition of hostility to the perceived US arrogance. Brand differentiation from the United States may be better. That way we will also do what we do best: be Australian.

The Austrade advice seems to present us with a dilemma: be an Australian and be a loser, or renounce your identity in the name of profit. But this dilemma may be just the product of a limited concept of identity. The term derives from the Latin idem, 'the same', cognate with 'identical'. The term 'identity' has broadened to indicate those aspects which make a group unique, while the meaning of idem as 'the same' persists, depending on which connections we wish to emphasise.

Australian identity can be what some of us have in common with some Australians, and not others. This may easily be what we have in common with other non-Australians also: Australian soccer fans have a common identity with Brazilians or Argentinians, perhaps more than with many Australian rugby fans. Identity is what we have significantly in common, which creates connections. In a global world where connection is a primary rule to survive and thrive, Australian identities need to emphasise the characteristics we possess that help us to connect, not those that place us in a box.

\section{Do we need a national brand?}

In August 2009 the then government announced a plan to develop a national brand image. In February 2010 Malcolm Long, communications consultant and member of the Australian Communications and Media Association, floated a discussion paper to promote the idea. Under the heading Rebranding 
Australia, he argued that the task is long overdue to initiate a project that will 'effectively position and brand Australia in the global market place'. His core premise was that:

For a country to make its mark in the information-rich, competitive, borderless world we now inhabit requires strategic positioning and consistent and coherent branding. This is a requirement for whole nations as much as it is for industries and products. These days a nation's branding - its personality — must be distinctive, to rise above the new global digital din.

Long's paper provoked 132 replies, only two of which were positive. The first posting, by 'Fed up', was typical:

Australia is a continent - rich in diversity and multi-dimensional in the extreme. What's the slogan for the US, UK or France? Would it help them to have one? In fact do 'grown up' countries want or need them?

Have a brand strategy by all means. Let it help shape the story we want to tell across tourism, business, culture, etc. But let's not delude ourselves that a slogan, logo or campaign holds the answer.

The overwhelming trend in these responses shows a similar quality to Walker's response to Austrade. There is majority resistance from ordinary Australians to be described under a single slogan, whatever its content. They do not recognise the truth in their experience of any one label. If those it is meant to describe reject it, how will it work for a moment in the world outside?

Long assumes that everyone benefits equally from such a branding exercise, which he sees as a special adaptation to the new conditions of a borderless global world. But in the borderless world he talks about, why or how is a nation still a useful brand, and to whom? Some have criticised the idea of container nationalism, the way of thinking about world affairs as if each nation effectively acts as a container of its national essence, homogeneous within fixed borders. ${ }^{5}$ Container nationalism is not a useful way of thinking about the complex flows across boundaries which characterise the world of global business today.

Faced with this potential contradiction, Australian business people looking to Latin America can reasonably be sceptical of the aims and assumptions of a government project of nation-branding, and instead ask: What version of the nation would help me, in concrete ways, in my plans, and how would it help?

5 Andrew Wimmer and Nina Glick Schiller, 'Methodological nationalism and beyond', Global Networks 2: 4, 2002, pp. 301-34. 
And looking outside Australia to the many nations to be found in the broad region of Latin America: What images emanating from those sources will help me to conduct good business?

By asking these questions, about both Australia and Latin American nations, Australian business people can secure both economic and personal benefits. They can develop a dual perspective, from outside and from inside, of their own culture and another culture. At the same time they can realise the important truth that provides a guiding thread through the multiplicity of versions of cultural difference: Australians and Latin Americans alike want to learn things about the other on which to base actions and decisions.

Even if they risk being blacklisted by Austrade, they do not - to rely on a useful Australian term — want bullshit.

In May 2010, Brand Australia was launched, with the slogan Australia Unlimited, a four-year campaign costing \$A20 million. The research it commissioned and assembled is a useful starting point for informed reflection. The data draws on substantial numbers of international informants, and all say much the same thing. Australia is perceived as 'a vibrant, friendly and welcoming nation, with values of positivity, energy and practical solutions' ${ }^{6}$ These are the qualities projected by Paul Hogan in his Crocodile Dundee movies, popular in the United States and Latin America: the Lara Bingle and Baz Lurhmann-themed campaigns have come and gone. Hogan's campaign to promote Australian tourism remains the benchmark.

In contrast, it is hard to see what the vacuous slogan 'Australia unlimited' could mean to anyone, in Australia much less Latin America, or how it expresses the qualities the research identified. To translate this slogan into behaviours, how would you walk into a room of potential Latin American partners and act 'unlimited' (ilimitado/a/s in Spanish and Portuguese)? Wave your arms wildly? Speak loudly? Promise too much? It sounds uncomfortably like the caricature Yank mocked by Walker. The phrase translates badly. This is not because something that makes good sense to English-speaking Australians somehow does not translate to speakers of Spanish or Portuguese. On the contrary, the phrase is bullshit, to use the good Aussie phrase. Trying to translate it only exposes the fact.

The responses to Long's discussion paper reinforce the conclusions of Brand Australia's international studies. The Australia that Long and the Brand Australia campaign ignore is a complex, diverse mix of qualities, some old, some new. The

6 Australia Unlimited, 'Research: TNS Research for Building Brand Australia'. 
package as it has evolved is valued in similar ways by Australians as by the rest of the world. It is a useful starting point for reflections on what we are like, as Australians exploring a new world that includes Latin America.

\section{What is the real larrikin?}

With three colleagues I wrote a book trying to find out what a larrikin is today. ${ }^{7}$ This was based on a three-year project funded by the Australian Research Council, designed to determine whether this concept was still relevant for the world of business today, and, if so, how? We were interested in how these qualities work on the global scene, specifically in the new conceptual territory between Australia, Brazil and Mexico in which flows are beginning to take place. We asked whether the term is an anachronism, a distraction from new identities Australians need to adapt for the 21st century. Instead we found that in this new environment the larrikin tradition has already morphed into productive new forms.

Some of the results of our research are relevant to the paradox of identities this chapter began with. We found that many Australians in different kinds of organisation think that there is a distinctive, valuable way of doing things which they see as Australian. We also found that many Australians repudiate these qualities. The opposing positions in the debate between journalist Frank Walker and David Howe, trade commissioner in New York, concerning identification with an image of Australian identity and repudiation of it, are repeated at every level of Australian society. Australians are united by this division, not by denying one or other half of it.

That means that the brand that David Howe supports would be repudiated by Frank Walker, and vice versa. This may seem like a contradiction, which would be a nightmare for a marketing campaign. However, the opposite can also be true. Instead of trying to market one or other quality, a good campaign needs to market the contradiction: Australians are informal and effective.

I illustrate the contradiction through two representative quotations from our set of interviews of Australians, Mexicans and Brazilians, including Mexican and Brazilian Australians. Robert was an Australian middle manager, originally from Britain, offering his ideas on what a larrikin or Australian way of doing things is:

7 Bob Hodge, Gabriela Coronado, Fernanda Duarte and Greg Teal, Chaos Theory and the Larrikin Principle, Stockholm: Liber, 2010. 
It's irreverence or seemingly irreverence for people in authority: a readiness to break rules rather than accept them rigidly. That this is the way things should be done. The larrikin will look and say 'Oh yeah, there's a better way of doing it. We won't do it that way because we can do it better.'

Liana, a Brazilian Australian executive in a small enterprise had a different take:

[Australians] accept that they have to follow the rules and the normal bureaucratic process. On the other hand, it is interesting to observe that in Australia-I saw the statistics - for example, if in Brazil it takes a year to start a company, in Australia it takes a day. It is a country where bureaucracy has been eliminated. Just compare that in Brazil we come and say 'Ah, this document needs three stamps, etcetera'. Here it is much more simple: if someone signed it you believe.

Each interviewee appears to be describing a different Australia with opposite qualities to the other. Yet they both like it. Their judgements are comparative. Robert does not mention Britain, but that is his point of reference. Liana mentions Brazil, and it is probably the reference point for both of her judgements, even though she is not asked to make comparisons.

Neither of these people feels unable to understand the Australian system. Both have lived in Australia for many years, and both have reached reasonably senior positions, though both also know what life is like at lower levels. Far from being disabled by her Brazilian background, Liana is more able to cut through the myth of Australian irreverence for authority. Yet she also sees a contradiction, which she includes in her view, even though she cannot explain it: the easiness of bureaucratic processes in Australia compared to Brazil. She understands and admires the advantages of the Australian way, in contrast to the Brazilian nightmare.

Robert likewise is insightful, distinguishing between the appearance ('seemingly') and the reality of larrikin attitudes to authority. The example he gives is not negative, destructive rebellion but an independent, genuine commitment to the goals of the organisation and the demands of the particular task. His picture is not the same as Liana's, but it connects with it. Combining them with many other versions from our interviews, we obtained a version of the larrikin which positions its contradictions in relation to different areas of national experience. British Robert reacts positively to the quality, as does Brazilian Liana. What holds the opposites together is stated by Liana ('you believe'), and implied by Robert: it is trust.

Both Liana and Robert use national categories to think with, to organise their generalisations about working life in Australia and other parts of the globe. 
For each, Australianness is a flexible category, not a one-size-fits all concept. In Liana's case, as was typical of our Latin American interviewees, the national category, here Brazilianness, was not a container category-comprising all the diversity of her country into a single word-but a connecting category. She compares a patch of life in Brazil with a related patch of life in Australia.

One lesson from this small sample is that Australianness can matter and make sense, to Australians and Latin Americans alike, even if it is not a single, coherent category as presented in a brand-marketing campaign. On the contrary, Australians and Latin Americans will develop their own generalisations about the other from intelligent observations of actual behaviours.

Australian managers do not fit a larrikin stereotype, but this set of qualities and orientations flavour how they tend to run businesses: 'Australian managers are more humanistic, shrewder, less pompous and more subtle than their performance-obsessed American counter-parts, and are happy to play down performance if it threatens their quality of life' ${ }^{8}$

These qualities may sometimes be responsible for lower rankings of Australian managers in international comparisons. ${ }^{9}$ This outcome confirms David Howe's concern that Australian qualities may not impress US managers, especially on first meeting. Paradoxically it also gives reasons to agree with Frank Walker that even in the United States these qualities may be valuable. In Latin America, the Australian way, with integrity above all as a defining quality, is likely to impart a competitive advantage.

\section{'Cultural sensitivity' and the American way}

Modern global corporations are aware they need to be sensitive about the cultures of different peoples they conduct business with. 'Cross-cultural training' and 'cross-cultural management' are part of the tool-kit of Australian business people today. In this chapter I applaud this awareness. A book such as the present one is an ideal occasion to contribute to this worthy goal in the Latin American region. Yet there are some significant problems with the predominant form of theory and beliefs among those who shape attitudes and agendas in this area. These agendas need to be addressed to allow cross-cultural management and other cross-cultural interactions to work better.

Part of the problem I suggest is the excessive influence of the US style of management in Australia, as in business education in Latin America. This style

8 Spillane, Robert, in Paul Davidson and Ricky Griffin, (eds), Management: An Australian perspective, 3rd edn, Brisbane: John Wiley \& Sons, 2005.

9 K. Marshall, 'Local bosses best at human touch', Australian Financial Review, 28 November 1997, p. 59. 
dominates our university courses in management. These are fed by textbooks published in the United States, shaped by US experiences, attitudes and preconceptions. Yet as indicated earlier, Australia is not the United States. We can have a competitive advantage by doing things differently, in an Australian way that is more responsive to currents and tendencies in Latin America. Our managers are currently trained to see the rest of the globe through US eyes. We need to turn this gaze around, and look critically at how US eyes look at the world, and how that world looks back.

To illustrate what is being taught in our business schools, as in business schools in the United States, I quote from Helen Deresky, whose books on International Management are used in most Australian universities. ${ }^{10}$

Deresky emphasises the importance of cultural sensitivity, a main theme of her work on international management. She begins with a satisfactory definition: 'Cultural sensitivity, or cultural empathy, is an awareness and an honest caring about another individual's culture'. ${ }^{11}$

But this quality is rare in US businesses, she says. American managers' knowledge of other cultures lags behind their understanding of other organisational processes. Deresky cites studies that show that up to 40 per cent of US expatriate managers leave early because of poor performance, and half of the rest are only 'marginally effective'. That is, only 30 per cent are above a 'marginal' level. Deresky promises to turn this around through the influence of her book. But it might be more constructive to ask why this training is as defective as the figures indicate, rather than placing ourselves in the unsafe hands of the American Way.

A key problem of the American Way can be seen in Deresky's endorsement of the idea that American managers understand all competing organisational processes: that their only blind spot is their lack of knowledge of other cultures. What if the real blind spot is the belief, which she shares, that the American Way is consonant with the One True Way? She does not appreciate the problems that may stem from US managers' confidence in the superiority of their methods. She does not see this as arrogance, or note its effects. As I have said, this is a key difference between Australian and US styles of management and conducting business. This difference will not be cured by adding superficial US-style cultural sensitivity to basic US-style models of managerial and business behaviour.

10 See B. Hodge et al., op. cit., note 7; Helen Deresky, International Management: Management across Borders and Cultures, Pearson/Prentice Hall, 2005.

11 Deresky, op.cit. note 10, p. 83. 
One example can illustrate the inadequacies of Deresky's advice for greater cultural sensitivity. She classifies all Latin American people under the heading 'polychronic', from Greek, 'of many times':

Polychronic people-Latin Americans, Arabs, and those from other collectivist cultures - may focus on several things at once, be highly distractible, and change plans often. ${ }^{12}$

We note here that a theory of cultural sensitivities and awareness of difference assumes no differences between people from different Latin American nations, or between Latin Americans, Arabs and others not specified here. Only one cultural difference matters, between Us (Anglo-Americans) and Them.

'They' are made to seem 'distractible', unable to cope with or keep to their plans. Not like Us, who are rock-solid, focused on only one thing at a time. But if They are misrepresented, so are We. In modern business practices, no-one has the luxury of being monochronic. 'We' all have to be multi-tasked, multi-skilled, mobile in time and space. Being polychronic and flexible is a virtue in the new global work environment.

Deresky's fatal flaw, typical of US writers on cross-cultural management, is her use of the ideas of 'culture' and 'cultural sensitivity' to blind herself to power and its role in the long history that leads to the unequal present. Culture has been misused in business circles to misunderstand important issues that need to be seen in the first instance as political. Cultural sensitivity needs to begin with a short history lesson.

The term 'culture' derives from Latin colo, meaning to plough, and hence to work, to improve by work, to live in a place and to worship its gods. These four meanings still underlie the set of meanings of 'culture/a' in English, Spanish and Portuguese. In this area Australians and Latin Americans share more or less the same word. But all these meanings are distorted by the operation of another word possessing the same root. Latin colonia was a soft way to refer to a process whereby Greeks and Romans made incursions into another peoples' territory and took over the land, exploited it and lived there as if it were their own. 'Colonial' has the same basic function for each of these societies: Greek and Roman in the past; Spanish, Portuguese and English in the 16th century; the United States today.

The wars of independence in Latin America used the rhetoric of revolution, influenced by the ideology of the revolutions that were being played out in Europe, triggered by the French Revolution. Yet the real winners of these wars 
of independence were local power elites. They created highly unequal social structures which reproduced themselves for the next 200 years, still major forces in the Latin American present.

Before the Latin American revolutions and inspiring them was the American War of Independence, the radical break with the British imperial power which gave the United States its foundational charter. Yet this position embodied a contradiction which continues to the present. This is crystallised in the Monroe Doctrine, first enunciated in 1823 by US President Monroe. Monroe's liberatory message to European powers warned them against further colonisation in the Americas. By 1845 this had morphed into the doctrine of Manifest Destiny, the idea that the United States retained the right to dominate the Americas. This double message - the United States as champion of freedom and as colonial power - still creates tension and ambivalence in Latin America today.

In the early 19th century Australia was too insecure a colony to seek independence. In 1901 it achieved partial autonomy with Federation. Over the rest of the 20th century it crept towards greater autonomy, but the 1999 Referendum on whether to become a Republic was defeated. I have always found this fact difficult to explain to Latin American friends, who are bewildered. How could a modern nation like Australia still technically be a colony of a European power in the 21 st century, complete with a Queen?

Brazilian theorist Darcy Ribeiro argued that Latin American nations were formed by the mixture of civilising processes, European and indigenous, producing the inequalities that mark these nations today. ${ }^{13}$ Mexican anthropologist Guillermo Bonfil Batalla adapted Ribeiro's model to Mexico, which 500 years after the conquest he saw still divided between the Spanish-based society and a 'civilization denied', which he named 'México Profundo': deep Mexico. ${ }^{14}$ His 'deep Mexico' is formed by interactions in which a dominant culture both suppresses and feeds off an indigenous culture. This deep culture has evolved over 500 years, he says, adapting to the dominant culture, absorbing and reframing some of its attributes. Hodge and Mishra ${ }^{15}$ saw a similar model in Australia marking the ambivalent relationship of its Anglo-Celtic majority to Aboriginal culture and to the fact of the dispossession of Aboriginal people.

The Ribeiro-Bonfil Batalla model applies to the whole of Latin America. It also applies, with differences of history and context, to both Australia and the United States. All were created on a similar foundation. Acts of invasion and dispossession created initial disparity, maintained by sharp divisions. In all

13 Darcy Ribeiro, Las Américas y la civilización, Buenos Aires: Centro Editor de América Latina, 1969.

14 Bonfil Batalla, Guillermo. México profundo: Una civilización negada, CONACULTA, Editora Grijalbo: México, 1987.

15 Bob Hodge and Vijay Mishra, Darkside of the Dream, Sydney: Allen and Unwin, 1991. 
these nations, indigenous people were dispossessed to differing degrees, but never eliminated. In the case of Brazil and the United States, slaves became a more prominent part of the landscape. But these and many other differences make better sense by putting them in a common frame.

Many Australians feel uncomfortable about seeing their history in this way. In academia it was debated in what was called 'the History Wars' ${ }^{16}$ Those outside academia may have been puzzled what the point of the battle was, because everyone agreed on the main point. Australia was founded as a result of dispossession of its Aboriginal people, as happened in the whole of the Americas, North and South. Australia has its own 'Australia profunda' to echo 'México profundo', 'Brasil profundo', 'América Latina profunda'.

If we accept this, then we can have better, more honest conversations with Latin Americans. In the process we may learn more about Australia, as well as about Latin America.

\section{The Aussie way as transnational good}

I have argued that the Aussie way of doing things can be more valued and valuable for Australians in Latin America than many believe. This is because it is less unique than is usually presented or is understood by most Australians. It allows us to connect better, and connections are the new rules of the global game.

The Larrikin Principle can be seen in this respect as a series of solutions to more general problems of power and authority. Such problems have not disappeared, in Australia or the rest of the world. Nor have the solutions become irrelevant: scepticism about authority, flexibility and creativity, openness, loyalty, trust.

There are good reasons for the deep affinities that can be felt between the Australian way and attitudes and values in Latin American nations, in addition to the common colonial origins and histories. In the first place, there are common elements in earlier forms of all these traditions. The larrikin tradition had origins in Irish Catholicism, and later influxes of migrants from Catholic countries like Italy added to the strength of Catholicism, which is now Australia's largest religion by number of adherents.

Behind Catholicism lay earlier non-Christian traditions, which blended with indigenous traditions to form the wonderful syncretic religious forms that are so attractive in Latin America. These drew on and carried indigenous elements across Latin America, and also African elements, especially in Brazil, the United

16 Stuart MacIntyre and Anna Clark. The History Wars, Melbourne: Melbourne University Press, 2003. 
States and the Caribbean. These forms of culture are attractive to Australian tourists, extending their identity in unconscious ways. The larrikin tradition itself has roots in European folk traditions. 'Trickster' figures like the traditional larrikin are found in very ancient forms in Africa, Asia and the Americas as well as Europe and Aboriginal Australia. This aspect of Australian identity is fed by pre-modern global roots as well as post-modern needs.

A culture is also a set of ways of solving problems. Latin American countries are all still constrained by patterns of authority that have been around so long that they appear to be part of the identity itself. Liana identified stultifying bureaucracy as the Brazil she would not miss. Other Latin American nations have similar problems.

In this situation, Brazilians have developed a set of strategies called the jeitinho. ${ }^{17}$ The term derives from jeito, a way (of doing things), plus inho, meaning a short cut; cutting through bureaucratic tangles, in the diminutive form, which imparts a familiar, affectionate flavour to the word. Mexican Spanish has a similar diminutive in -ito. So favor, bending the rules, becomes favorcito. Mexicans have other words for related practices: e.g., palanca, literally a lever, is something that gives an advantage.

Informal Australian English has similar form and content. Adding -ie makes rule-bending seem harmless. Australian workers who take a day off for personal reasons but claim sick leave call it a 'sickie'. Bending rules to benefit someone you know is called 'mates' rates'.

Brazilian sociologist Roberto DaMatta connected the jeitinho to what he saw as the dysfunctional nature of Brazilian society:

It is alarming to see that daily legislation in Brazil is a regulation of the 'can't do' .... It is precisely because of this that we discovered and perfected the jeitinho, a style of social navigation that is read between the lines of these peremptory and authoritarian 'can't do's'. ${ }^{18}$

DaMatta reads this quality not as a consistent attribute marking a stable identity, but the opposite. His Brazil today is full of contradictions. It is internationally famous as a symbol of exuberance, beauty and joy, yet the disparity in income of the wealthiest 20 per cent and the poorest 20 per cent makes it among the ten most unequal nations in income distribution in the world. He eloquently captures some of its contradictions:

17 Fernanda Duarte, 'Exploring the interpersonal transaction of the Brazilian jeitinho in bureaucratic contexts', Organisation 13/4, 2006, pp. 509-27.

18 Roberto DaMatta, O que faz o Brasil, Brasil?, Rio de Janeiro: Editora Rocco, 1984, p. 98. 
In Brazil we have carnivals and hierarchies, equalities and aristocracies, and cordial meetings full of smiles giving away the very next moment to the terrible antipathy and violence of 'Do you know who you're talking to?' We also have the samba, cachaca [sugar-cane brandy], the futebol [soccer], but this all occurs in the midst of what came to be called a 'relative democracy' and a 'Brazilian-style capitalism', a system in which only the workers run the risks and from which they draw no profits. ${ }^{19}$

In this kind of situation, figures emerge whose role is to fix the problems of a broken society. For instance, despachantes (from despachar to finish or resolve a problem) are people who work as trouble-shooters in Brazilian society. They are a Brazilian version of the larrikin principle, shaped by the specific forms of dysfunctionality in Brazil. Mexico has an analogous role, commonly called coyotes. As the term implies, coyotes are dangerous tricksters, not to be trusted.

Despachantes are paid for tasks such as queuing for people in public service institutions, and sorting out bureaucratic problems related to processes such as driving licences, electoral documents and identity cards. They constitute one of many cybernetic loops whose role is to correct the huge inefficiencies of Brazilian bureaucracy. Carlo a despachante gives this portrait of the role: 'You must be patient; you must listen to people's stories first. Things will happen at the right time, and you must have patience to listen'. Carlo clearly does not have the opportunity to practise his samba steps or take a swig of cachacha while he listens carefully and waits patiently. He has absorbed the contradictions of society into contradictions in his own being, at whatever pain and cost. Clearly he does not do this because as a Brazilian he likes to, but because he has to.

Carlo is not a larrikin, but his conditions are eminently understandable to Australian readers. Business people can imagine what it would be like to walk in his shoes. From the other side, Carlo could immediately understand and respect the different conditions that Australians work under, as Liana did. Brazilian conditions and strategies go hand in hand, as do Australian ones. Cross-cultural understanding in this case, as in others, does not require socialisation from birth into the mysteries of playing futebol for a Brazilian or downing large amounts of beer in a single draught, as legendary Aussie Bob Hawke reputedly did. The conditions are different, but those differences can be understood, and the aspirations are the same. It is a good enough basis for Australians to understand Latin America, and to be accepted in return. 


\section{The shadow of corruption}

This chapter argues that there is much in common across the ocean which separates Australia from Latin America. Respect and appreciation are keys to mutual understanding. Yet there is also a dark side of Latin American life which must be acknowledged and dealt with, for it will not go away. Corruption is like the elephant in the room: so big that everyone knows it is there, but too problematic to talk about.

That may seem a surprising statement. Corruption is often talked about as a problem for businesses carrying out country risk assessments. There is an international monitoring agency, Transparency International, which assigns an annual index to each country. ${ }^{20}$ That is true. Yet this section will suggest that the corruption talked about and measured is a substitute to distract from addressing the real thing. There is serious corruption at government levels in Latin American states, but diplomatic sensitivity means that it cannot be talked about. Agencies like Austrade cannot report at length on these issues because that would breach diplomatic protocols.

'Corruption' is a loaded word with many meanings, but at its heart is the idea of a system-wide breakdown in processes that sustain that system. As a metaphor, corruption is like the spot on an apple which expands to cause the whole apple to rot. Or to use another strong metaphor, corruption is like the way a fish rots from the head. Individual acts of theft or fraud do not of themselves constitute corruption, unless they affect governance itself.

Corruption in this sense applies to the ruling regime in Colombia, where the USsponsored war against drugs is implicated in a state infiltrated by drug interests. In Mexico, three of the past five presidents were elected under widespread suspicions of electoral fraud. These frauds cannot be proven because systems to check against them are compromised. That is a sign of even deeper corruption than the alleged frauds.

For Australian business people this creates a dilemma. What are they to do with such knowledge as they have about corruption? About most aspects of a country, the more you know the better, but not in this case. Australian citizens in a foreign jurisdiction would be unwise to become involved, or open any cans of worms. For government officials even less is possible. Given that all these nations are classified as friendly states, issues of high-level corruption and complicity in corruption simply cannot be raised in public.

20 Transparency International: the global coalition against corruption, Corruption Perceptions Index 2012, http://www.transparency.org/cpi2012/results. 
Here it is useful to distinguish between governments and nations. Even in a democracy like Australia, the government in power is elected by a small majority. Its members claim to speak on behalf of a nation of people, nearly half of whom did not vote for them. In the debate about Australia's national brand, problems arose from the fact that the state controls the branding of a nation, many of whose members strongly disagree with the state's definitions of them. The same is true in Latin America. These nations are their people, not their governments. Governments cannot be ignored, and systems of governance affect the life of everyone in the nation, including foreign business people from Australia. Yet the distinction between state and people shows a way between rejecting deep corruption and understanding ordinary citizens.

In practice, corruption is commonly dealt with in relation to Latin America by redefining it, so that the 'corruption' that is denounced and campaigned against is something other than the serious corruption that is the real problem. As a striking instance of this process at work, Gabriela Coronado reported on a sign she noticed in 2008 in Polanco, a wealthy district in Mexico City. ${ }^{21}$ The sign depicted a large image of a bottle of Coca Cola. At the top was the phrase, in colloquial Spanish $\mathrm{Pa}^{\prime}$ ' chesco, literally '[money] for a cool drink', but metaphorically a request for a tip. Below was the following: 'We are thirsty for honesty: 'No to corruption. United for Honesty.'

This was part of a campaign by a local business association, supposedly against corruption. But corruption here is symbolised by the custom of workers asking for a tip. Big business presents itself as thirsty for honesty, not for a coke. But one presumes that they will drink imported whisky without a problem, along with the soda of their honesty. For them, corruption is what others do, not their own practices. Campaigning against the corruption of others - especially those who cannot defend themselves - is a desirable form of attacking corruption for those who are corrupt. Anti-corruption campaigns like this help to increase corruption.

The target of this campaign is the informal systems that have developed in Latin American countries, as if these were the problem rather than a solution to the often-dire situation of many citizens. It is true that the informal economy is burgeoning in Mexico and other Latin American countries, as a product of government measures often driven by neoliberal policies. It is also true that the total system, consisting of the formal and informal economies, is often incoherent and dysfunctional. But the solution is not to remove the informal system, without which the society and economy would collapse. Alternative forms of payment, often barely enough to survive on, are not the problem. Blaming them prevents a proper understanding of the problem.

21 Gabriela Coronado, 'Discourses of Anti-corruption in Mexico: Culture of Corruption or Corruption of Culture?' Portal: Journal of Multidisciplinary International Studies, 5(1), January 2008, pp. 1-23. 
The 'Australian way' of doing things as advocated by the Larrikin Principle gives greater value to informal practices, to doing what has to be done in order to get by. The relaxed Australian way of adapting rules where they do not apply is the commonsense response to so-called 'anti-corruption' campaigns like this one.

The same reasoning applies to the way corruption is officially described and measured by international agencies as guidance for business people, Australians and others. The defining marker of corruption is the presence of bribes: payments outside a regular schedule of costs. No one likes paying any more than a listed cost, and the need to pay bribes is irritating and inconvenient, for Australians as for Latin Americans. However, in many cases these extra costs can be regarded as an incentive for functionaries who are not paid enough to survive on their normal salaries.

Business the US way is also run by financial incentives: performance bonuses for top executives and sales staff, free gifts with commodities, etc. This may not always lead to efficiencies in US and Australian business practices. It may sometimes produce serious corruption, as in the case of Enron's bonus system. ${ }^{22}$ This is not called 'bribery', much less 'corruption', because it is accepted business practice. Yet the principle is the same. Tips in restaurants are not called bribes, either, yet they too are similar in principle. In each case, extra money ensures that an under-resourced system limps along in a better way than if those incentive payments were not in place.

This double standard provides a flawed basis for international systems of surveillance. As mentioned earlier, the international body, Transparency International, purports to monitor levels of corruption in countries through the propensity to take bribes, which it uses as its main proxy for estimating levels of corruption. In the 2012 index, New Zealand came equal first, and Australia a very respectable seventh out of more than 150 nations. The United States squeezed into the top 20 at 19. Of Latin American nations, Chile came a respectable 20th, but Brazil was at 69, Peru at 83, Argentina at 102, and Mexico equal at 105 with Bolivia. ${ }^{23}$

Does that mean what it seems to? As argued above, bribes at this low level are poor indicators of serious corruption. Another problem with this measuring instrument is that it only measures reports of those who paid bribes. These are ordinary victims of corruption rather than perpetrators. It relies on their honesty in making the reports. It does not ask the seriously corrupt to indicate how corrupt they are, because the seriously corrupt do not fill in questionnaires, and sensible social scientists do not ask them to. As a result the figures country-by-

22 Bethany McLean and Peter Elkind, The Smartest Guys in the Room, Harmondsworth: Penguin, 2003.

23 Transparency International, Corruption Perceptions Index, op. cit. note 20. 
country make the problem seem to arise from the large number of victims who have paid the bribes, as though this is somehow their fault, as if the problem would go away if these ordinary Mexicans, Brazilians or Argentinians did not gratuitously hand over this money.

Yet considered carefully, the broad tendencies indicated by these figures do say something. Aussies and Kiwis do have a reputation for not being corrupt, for being good citizens - and it is a precious asset. Americans are less trusted, and corruption is indeed endemic in Latin American countries.

There are four main lessons for Australians doing business in Latin America.

1. Make a large distinction between what is called 'grand corruption' and 'small corruption'. Grand corruption is immoral, unethical and usually criminal. There is no need for 'cultural sensitivity' over grand corruption. It is denounced by all Latin American governments, whatever complicity they may have in practice. It is rejected by most Latin American citizens, good people who are victims of these practices.

2. Do not trust campaigns against corruption, national or international. Their basis is so flawed that they are worse than useless, since they foster the belief that they provide some guidance to complex issues.

3. Do not use the powerful, vague, emotive word 'corruption' for the range of informal systems found in Latin American life. Call the practices by their specific names. Avoid those that you can and wish to, especially if they are currently illegal in some way, as some - but not all-bribes are. But do not see yourself or those you do business with as corrupt if these become the terms in which you do business. Do not feel shame or guilt, and do not blame these individuals. Save the label corrupt for the small minority of wealthy and powerful citizens of Latin America and other states-including the United States and Australia - who engage in seriously corrupt behaviour.

4. Do not be corrupt yourself. Treat your integrity as a more vital part of your Aussie identity than putting another shrimp on the barbie, or calling everyone 'mate'.

\section{Conclusion}

This chapter has argued that cultural sensitivity is sometimes a counterproductive way of achieving goals which are themselves admirable: of improving understanding between individuals, businesses and nations, in this case Australia and Latin America. By emphasising difference under the name of culture, it makes the differences seem absolute and hard to understand or negotiate. That is unhelpful if the aim is to increase the wish to understand 
others. Nor does it describe the situation adequately. Australians have many differences between them, which are part of the fabric of life which we deal with every day. People of Latin America similarly possess many differences. To emphasise what they have in common as completely different to what Australians have in common is to miss all the many ways in which Australian characteristics are recognisable and valued in Latin America, and vice versa. By imagining Latin Americans as unimaginably different from us we cannot hope to understand them. The cultural sensitivity paradigm replaces the realities of Australia and Latin America with fantasies about both. That is not a good basis for forming any kind of relationship, in business or in other spheres of life.

There are three applications of these principles for different stakeholders:

1. Australians, in government and business alike, should accept Australian values that have emerged over time as a complex reality and asset to build on. These should provide the basis for business and government strategies alike.

2. Points in common in the history, politics and culture between Australia and Latin America need to be followed up, as networks of understanding, in order to frame a better understanding of points of difference. Anything that seems familiar probably is.

3. The understanding of the many things that it means to be Australian can be increased by attempting to understand and interact with Latin Americans. Go there, as tourists, as business people, as ambassadors, and interact with those at home as the diverse people they really are. That is how better understanding grows.

\section{References}

Austrade (Australian Trade Commission), United States of America: Doing business, http://www.austrade.gov.au/Export/Export-Markets/Countries/ United-States-of-America/Doing-business\#.UlohDBCBHIE, accessed 13 October 2013.

Australia Unlimited, 'Research: TNS Research for Building Brand Australia', http://www.australiaunlimited.com/page/brand-australia/media-tool-kit/ research, accessed 11 October 2013.

Bonfil Batalla, Guillermo. México profundo: Una civilización negada, CONACULTA, Editora Grijalbo: México, 1987. 
Coronado, Gabriela. 'Discourses of Anti-corruption in Mexico: Culture of Corruption or Corruption of Culture?' Portal:Journal of Multidisciplinary International Studies, 5(1), January 2008: 1-23, http:/epress.lib.uts.edu.au/ journals/index.php/portal/article/view/479/581, accessed 13 October 2013.

DaMatta, Roberto. O que faz o Brasil, Brasil?, Rio de Janeiro: Editora Rocco, 1984.

, Carnivals, Rogues and Heroes, London: University of Notre Dame Press, 1991.

Davidson, Paul and Ricky Griffin, Management: an Australasian Perspective, Melbourne: Sage, 2003.

Deresky, Helen. International Management: Management across Borders and Cultures, Pearson/Prentice Hall, 2005.

Duarte, Fernanda. 'Exploring the interpersonal transaction of the Brazilian jeitinho in bureaucratic contexts', Organisation 13/4 (2006): 509-27.

Hodge, Bob and Vijay Mishra, Darkside of the Dream, Sydney: Allen and Unwin, 1991.

Hodge, Bob, Gabriela Coronado, Fernanda Duarte and Greg Teal, Chaos Theory and the Larrikin Principle, Stockholm: Liber, 2010.

Marshall, K. 'Local bosses best at human touch', Australian Financial Review, 28 November 1997, p. 59.

MacIntyre, Stuart and Anna Clark. The History Wars, Melbourne: Melbourne University Press, 2003.

McLean, Bethany, and Peter Elkind, The Smartest Guys in the Room, Harmondsworth: Penguin, 2003.

Ribeiro, Darcy, Las Américas y la civilización, Buenos Aires: Centro Editor de América Latina, 1969.

Spillane, Robert, in Paul Davidson and Ricky Griffin, (eds), Management: An Australian perspective, 3rd edn, Brisbane: John Wiley \& Sons, 2005.

Transparency International: the global coalition against corruption, Corruption Perceptions Index 2012, http://www.transparency.org/cpi2012/results, accessed 13 October 2013.

Walker, Frank, 'Septics Are No Can Of Laughs', Sun Herald, 8 October 2006, p. 31, http://www.septics.com.au/septics-articles/2006/10/8/septics-are-nocan-of-laughs/, accessed 13 October 2013. 
10. Doing Business in Latin America the Australian Way

Wimmer, Andrew and Nina Glick Schiller, 'Methodological nationalism and beyond', Global Networks 2/4, 2002, pp. 301-34. 
This text taken from Australia and Latin America: Challenges and Opportunities in the New Millennium, Edited by Barry Carr \& John Minns, published 2014 by ANU Press, The Australian National University, Canberra, Australia. 